\title{
TINJAUAN YURIDIS SANKSI PIDANA TERHADAP PELAKU PELANGGARAN LALU LINTAS MENURUT UNDANG- UNDANG NOMOR 22 TAHUN 2009 TENTANG LALU LINTAS DAN ANGKUTAN JALAN
}

\author{
Oleh: \\ Rudolf Silaban \\ Indah Malau Pase \\ Universitas Darma Agung, Medan \\ E-mail: \\ banglabanshmh@gmail.com \\ indahmalpes@gmail.com
}

\begin{abstract}
Sanctions for offenders of road traffic and transportation violations are reviewed based on legal offenses, namely Law Number 22 of 2009 concerning Road Traffic and Transportation. In it, it is reviewed and determined that every violation related to traffic space is stipulated in the criminal provisions based on violations in traffic and road transportation so that the public can be aware and obey the law. It needs to be implemented strictly and not overlook anyone who violates traffic by referring to this law in order to reduce the risk of traffic violations and accidents. Based on the law on road traffic and transportation, obligations and prohibitions are regulated and are considered as traffic violations if they are not obeyed. The imposition of criminal sanctions for traffic offenders is applied based on the criminal provisions of CHAPTER XX article 316 (1). criminal sanctions for fines, imprisonment, even imprisonment for violations that are classified as serious. Based on the decision of Medan District Court No. the investigators' charges, so that the defendant would not be deterred or be able to repeat the same offending.
\end{abstract}

Keywords: traffic violations, sanctions, perpetrators.

ABSTRAK
Sanksi bagi pelaku pelanggaran lalu lintas dan angkutan jalan ditinjau berdasarkan
delik undang-undang yaitu Undang-Undang Nomor 22 Tahun 2009 Tentang Lalu
Lintas Dan Angkutan Jalan. Di dalamnya dikaji dan ditentukan bahwa setiap
pelanggaran yang berhubungan dengan ruang lalu lintas ditetapkan didalamnya
ketentuan pidana berdasarkan pelanggaran dalam lalu lintas dan angkutan jalan
agar masyarakat dapat sadar dan taat akan hukum. Perlu diterapkan secara tegas
dan tidak melewatkan siapa saja yang melanggar lalu lintas dengan berpedoman
pada undang-undang tersebut agar dapat mengurangi resiko pelanggaran dan
kecelakaan lalu lintas. Berdasarkan undang-undang lalu lintas dan angkutan jalan,
diatur kewajiban dan larangan dan dianggap sebagai pelanggaran lalu lintas jika
tidak ditaati.Penerapan sanksi pidana bagi pelaku pelanggaran lalu lintas
diterapkan berdasarkan ketentuan pidana BAB XX pasal 316 (1).Penerapan sanksi
107 TINJAUAN YURIDIS SANKSI PIDANA TERHADAP PELAKU PELANGGARAN
LALU LINTAS MENURUT UNDANG-UNDANG NOMOR 22 TAHUN 2009 TENTANG
LALU LINTAS DAN ANGKUTAN JALAN
Rudolf Silaban, Indah Malau Pase


pidana dilakukan dengan menerapkan sanksi pidana denda, kurungan, bahkan penjara bagi pelanggaran yang tergolong berat.Berdasarkan putusan PN Medan Nomor 24570/Pid.LL/2020/PN Mdn, dapat dilihat bahwa penerapan sanksi pidana denda atau kurungan yang ditetapkan oleh hakim masih tergolong ringan jika dilihat dari pasal dakwaan penyidik, sehingga memungkinkan terdakwa tidak jera atau dapat mengulangi perbuatan melanggar yang sama.

\section{Kata kunci: Pelanggaran lalu lintas, Sanksi, Pelaku.}

\section{PENDAHULUAN}

Seseorang yang sudah dapat mengendarai atau mengemudikan alat kendaraan bermotor maka dapat dianggap sebagai subyek hukum yang sudah dianggap cakap hukum, diantaranya telah memilki usia dewasa,dan tidak dibawah pengampuan dalam mempertanggungjawabkan

kesalahanya yang berisi sanski atau hukuman. Namun seiring layaknya mewujudkan kemudahan dan akses masyarakat dalam memegang utama dalam perwujudan kegiatan pembangunan dan perekonomian tidak lepas dari yang sering menjadi problematika dalam masyarakat yaitu permasalahan lalu lintas dan angkutan jalan seperti kemacetan lalu lintas yang berlanjut pada pelanggaran lalu lintas dan dapat berujung terjadinya kecelakaan lalu lintas yang menyebabkan seseorang luka ringan,luka berat bahkan sampai meninggal dunia.

Kota medan adalah kota terbesar ke tiga di Indonesia setelah Jakarta dan Surabaya. Sebagai kota terbesar otomatis akan memilki jumlah penduduk yang juga padat, berdasarkan data Badan Pusat Statistik jumlah penduduk di kota medan sebagai kabupaten dan pusat kota ada sekitar 2,26 juta. Sebagai pusat kota mayoritas penduduk kota medan bekerja dalam bidang sektor ekonomi yaitu perdagangan.
Aktivitas ini otomatis membutuhkan sarana serta prasarana transportasi dalam mendukung kegiatan berbagai aktivitas warga baik dalam perekonomian ataupun kegiatan lainya. Seperti contoh angkutan umum serta ojek online (grab,gojek,in driver) serta mobil angkutan barang. Sebagian warga juga beraktivitas menggunakan kendaraan pribadi atau kereta dengan alasan angkutan umum kurang efisien waktu dan sering ugal-ugalan dalam melajukan kendaraan. Sebagai pengguna lalu lintas, penulis sering memperhatikan keadaan lalu lintas ang sembrawutan apalagi jika sudah mendekati perhentian atau lampu merah.Kemacetan pada jam-jam sibuk lebih mendominasi pengendara melakukan pelanggaran dalam menggunakan ruang lalu lintas ditambah tidak adanya polisi yang bertugas mengatur lalu lintas. Pelanggaran yang muncul dan sering terjadi yaitu angkutan umum yang mengambil jalur lain dan nekat menerobos lampu merah dan diikutsertai juga oleh pengendara motor lainya, pengendara sembarangan memutar arah tanpa menggunakan lampu sein dan tidak memperhatikan keadaan lalu lintas, berkendara sambil menggunakan hp dimana konsentrasi berkendara jadi kurang fokus, serta masih banyaknya pengendara yang belum memilki SIM sebagai satu syarat sudah dapat 
mengemudikan kendaraan dan paling banyak yang ditemui adalah berkendara di bawah umur. Jadi tidak bisa dihindarkan sebuah pernyataan bahwa dengan adanya kemacetan malah menimbulkan pelanggaran lalu lintas serta dapat berakibat terjadinya kecelakaan lalu lintas. Kurangnya kesadaran warga kota medan dalam menaati ramburambu lalu lintas serta terlalu terburu-buru dalam mengambil tindakan yang merugikan diri sendiri dan juga orang lain baik itu pengendara lainya atau pejalan kaki yang berada dalam ruang lalu lintas.

Beberapa pelanggaran lalu lintas juga banyak dilakukan oleh pengendara jika terjaring razia oleh satlantas di beberapa titik kota medan, Angka pelanggaran lalu lintas berdasarkan data dari operasi zebra 2019 tercatat adanya peningkatan 5 persen dibanding 2018. Sekitar 53.659 pelanggaran lalu lintas diantaranya yang paling banyak adalah kendaraan roda dua yang pelanggaranya seperti tidak menggunakan helm SNI, melawan arus lalu lintas, serta berkendara dibawah umur. Pelanggaran yang dilakukan oleh mobil atau pengendara khusus didominasi suratsurat tidak lengkap, tidak menggunakan safety belt, hingga berkendara sambil menggunakan handphone. Dari beberapa hal diatas dapat dikatakan memang warga kota medan yang memakai lalu lintas banyak tidak mematuhi aturan lalu lintas serta rasa takut tersebut hanya pada saat razia selebihnya perbuatan itu akan diulang kembali tanpa sadar akan resiko yang dihadapi. Namun ada juga beberapa kejanggalan dalam razia dimana polisi dianggap masyarakat hanya karena tidak ada uang makanya mengadakan razia. Asumsi masyarakat muncul karena penerapan sanksi tilang pada saat operasi tidak berdasarkan ekstensi pasal-pasal dalam undang-undang lalu lintas dan angkutan jalan.Polisi yang bertugas cenderung bersepakat dengan pelanggar untuk membayar sejumlah uang damai yang dibawah ketentuan agar pelanggaranya tidak diproses secara hukum, dan pastinya uang damai itu dapat dikatakan masukan kas pribadi yang bertugas.Adanya orang dalam serta dapat menyuap polisi sudah umum bagi masyarakat jadi hal itu mengarahkan masyarakat pengguna lalu lintas tidak mengindahkan aturan lalu lintas.Bisa disuap yang penting aman.

Fenomena seperti ini
mengenai penanganan kasus pelanggaran lalu lintas telah menjadi suatu kebiasaan.Seperti dalam hal mendapatkan Surat Izin Mengemudi serta surat-surat kelengkapan kendaraan. Semua dapat secara manual tanpa praktek dan ujian karena jika mengikuti prosedur dianggap memakan waktu yang lama dan jika gagal otomatis akan diulang kembali. Dan yang paling parahnya dari beberapa anggota polisi dalam satlantas juga tidak mengikuti prosedur sesuai aturan dalam unndang-undang lalu lintas dan angkutan jalan atau masyarakat lebih memilih calo agar urusan pembuatan surat kendaraan atau mengemudi cepat keluar. Hal ini yang membuat masyarakat semakin yakin memang tidak ada sama sekali untuk apa Undang-Undang itu dibuat karena oknum yang bertugas juga tidak mengikuti aturan yang sudah diterapkan dalam undang-undang. 
Kecelakaan lalu lintas adalah suatu peristiwa di jalan yang tidak terduga dan tidak disengaja melibatkan kendaraan dengan atau pengguna jalan lain yang mengakibatkan korban manusia dan /atau kerugian harta benda.

Kecelakaan lalu lintas juga dapat dikatakan akhir dari sebuah kebanyakan pelanggaran lalu lintas yang kurang mengindahkan aturan lalu lintas sesuai undang-undang dan disebabkan kurangnya kesadaran masyarakat pengendara dalam mencari tahu arti dari rambu lalu lintas serta marka lalu lintas. Rambu lalu lintas pastinya tidak asing bagi kebanyakan masyarakat yaitu perlengkapan jalan yang berupa lambing,huruf,angka,kalimatdan,/per paduan yang berfungsi sebagai peringatan,larangan, perintah,atau petunjuk bagi pengguna jalan.marka jalan yaitu tanda yang berada diatas permukaan jalan yang meliputi peralatan atau tanda yang membentuk garis membujur,garis melintang,garis serong,serta lambing yang berfungsi untuk mengarahkan arus lalu lintas dan membatasi daerah kepentingan lalu lintas.

Dalam jaringan razia Operasi Zebra Toba 2019, Polda Sumut mencatat 98 kejadian kecelakaan lalu lintas dimana jumlah tersebut 32 orang meninggal, 24 orang luka berat, serta luka ringan 134 orang. Namun dalam kasus yang bertambah angka korban dinyatakan menurun dibanding tahun 2018 yaitu 44 orang meninggal dunia, 36 orang luka berat serta 85 orang luka ringan. Namun karena angka pelanggaran lalu lintas naik 5 persen serta itu juga yang mendominasi timbulnya kecelakaan lalu lintas Polda Sumuit berharap masyarakat berkendara harus lebih memperhatikan keselamatanya dan pengguna jalan lain agar angka pelanggaran lalu lintas serta kecelakan dapat ditekan.

Baru-baru ini berita terjadinya kecelakaan beruntun di jalan gagak hitam/Ringroad yang melibatkan 4 kendaraan yaitu Truck tronton, dua kendaraan pribadi serta mobil box Mitsubishi. Keadaan truk tronton yang mengalami rem blong serta menyeruduk kendaraan didepanya dapat dikatatakan akibat dari pelanggaran lalu lintas dalam faktor kendaraan yaitu adanya kelalaian perawatan yang dilakukan dalam kendaraan atau tidak adanya pengecekan ulang sebelum menggunakan kendaraan.

Dilansir dari harian mistar, diduga lalai dalam mengendarai mobil box dengan kecepatan tinggi, mobil tersebut menabrak mobil yang tengah terparkir di pinggir jalan. Bukanya berhenti tetapi supir tersebut banting setir ke kanan yang bersamaan dengan pengendara sepeda motor vario dari arah berlawanan akhirnya terjadi tabrakan yang tidak terhindarkan. Kejadian tersebut mengakibatkan pengendara berjenis kelamin wanita tersebut meninggal di tempat kejadian. Pelanggaran lalu lintas semacam ini sering dijumpai di jalan raya yaitu mengendarai kendaraan melewati batas kecepatan dan tidak memperhatikan situasi keadaan jalan yang ramai akan pengendara lainya. Perbuatan ini adalah termasuk melawan hukum dimana seseorang mengabaikan adanya aturan tata tertib lalu lintas yang dilakukan oleh pengguna kendaraan yang dimana akibat pengabaian tersebut dapat menimbulkan kecelakaan lalu lintas bagi pengguna jalan lainya. Dampak 
dari ketidaknyamanan pengguna jalan raya dengan kegiatan nya dapat menimbulkan semakin tingginya beban psikologis atau stress yang berkepanjangan, yang pada akhirnya dapat menimbulkan kejahatan lalu lintas baik itu karena kelalaian atau kealpaan seseorang dalam melaksanakan kewajibanya sebagai pengguna jalan raya yang tentu dapat merugikan orang lain.

$$
\text { Setiap orang yang }
$$
mengendarai kendaraan harus sudah memahami resiko yang dihadapi di jalanan, karna itu sudah tanggung jawab yang sudah diberikan kepada pengemudi, dan pengemudi tidak bisa dibebaskan dari hukum dari berbagai alasan apapun, ketika menyebabkan orang lain meninggal. Gott Fredson dan Hirschi (1990) mengatakan bahwa munculnya kejahatan lalu lintas yang menyebakan orang lain mati lebih disebabkan karena lemahnya kemampuan dalam mengortrol diri di jalan raya, seperti kurangnya konsentrasi mengendarai mobil, mengukur kecepatan, akurasi, serta pemahaman lalu lintas.

\section{TINJAUAN PUSTAKA}

Menurut Muhammad Ali, lalu lintas adalah berjalan, bolak-balik, perjalanan di jalan. Ramlon Naning mendefinisikan lalu lintas yaitu gerak pindah manusia dengan atau tanpa alat penggerak dari satu tempat ke tempat lainya. Subekti juga memberikan defenisi lalu lintas yaitu segala penggunaan jalan umum dengan suatu pengangkutanya. Sedangkan didalam KBBI menurut W.J.S.Poerdarminta menyatakan bahwa lalu lintas adalah berjalan bolak-balik, hilir mudik dan perihal perjalanan dijalan dan sebagianya serta berhubungan antara sebuah tempat dengan tempat lainya. Dengan adanya pendapat dari para ahli yang kosakata berbeda tetapi memiliki arah pengertian yang sama yaitu bahwa lalu lintas dapat diartikan seperti hal yang berhubungan dengan sarana prasarana jalan umum sebagai sarana utama untuk tujuan yang ingin dicapai. Sebagaimana yang kita tahu dari KUHAP, pelanggaran lalu lintas masih belum memuat semua jenisjenis pelanggaran yang umum dalam masyarakat. Maka dari itu dengan dikeluarkan dan ditetapkannya Undang-Undang yang baru(lex specialis) setelah diganti dari Undang-Undang Nomor 14 Tahun 1992 pemerintah berharap masyarakat lebih mengetahui tentang lalu lintas.Undang-Undang No.22 Tahun 2009.

Pada ketentuan umum pasal 1 ayat 2 bahwa Lalu Lintas adalah gerakan kendaraan dan orang diruang lalu lintas. Ruang lalu lintas yang dimaksud adalah prasarana yang diperuntukkan bagi gerak pindah kendaraan, orang, dan/atau barang yang berupa jalan dan fasilitas pendukung. Ada 4 komponen dalam lalu lintas yaitu pengemudi, jalan, kendaraan dan pejalan kaki yang saling berinteraksi. Chapter 2 Pelanggaran lalu lintas adalah suatu tindakan atau perbuatan yang melanggar ketentuan-ketentuan dan peraturan perundang-undangan yang mengatur lalu lintas dan angkutan jalan yang dilakukan pemakai jalan, baik perbuatan yang mengakibatkan kerusakan jalan, tidak lengkapnya surat-surat kendaraan, tidak paham akan rambu lalu lintas, serta kurangnya kontrol dalam mengemudikan kendaraan di jalan raya.Selanjutnya pemenuhan akibat hukumnya adalah adanya 
sanksi berupa sanksi administrasi, denda, atau kurugan.Sangat diharakapkan adanya kedisplinan serta ketertiban dalam berlalu lintas dalam mewujudkan cermin budaya bangsa.Sudah sewajarnya masyarakat khususnya pemakai lalu lintas menjalankan peraturan pemerintah sesuai perundangundangan yang ada.

Segala perbuatan yang bertentangan dengan Undang-Undang Nomor 22 Tahun 2009 Tentang Lalu Lintas Dan Angkutan Jalan merupaka tindak pidana. Berikut adalah bentuk-bentuk perbuatan atau tindak pidana pelanggaran lalu lintas Undang-Undang Nomor 22 Tahun 2009 Tentang Lalu Lintas Dan Angkutan Jalan, yaitu:

1) Pelanggaran peraturan berlalu lintas di jalan.

2) Pelanggaran peraturan kendaraan.

3) Pelanggaran pengemudi.

peraturan

4) Pelanggaran peraturan industri angkutan.

$\mathrm{Ke}$ empat diatas adalah tindak pidana pelanggaran lalu lintas yang tentunya terdapat sanksi yang berbeda-beda di setiap bentuk pelanggaran, karena dari bentuk pelanggaran lalu lintas tersebut yang tentunya menjadi munculnya unsurunsur yang menjadi faktor penyebab dan terjadinya pelanggaran lalu lintas, unsur yang dimaksud adalah dapat mempengaruhi kondisi lalu lintas, sehingga tujuan hukum dari adanya Undang-Undang Nomor 22 Tahun 2009 Tentang Lalu Lintas Dan Angkutan Jalan tidak bisa dicapai.

\section{METODE PELAKSANAAN}

Jenis penelitian yang diteliti penulis ialah metode penelitian normative yuridis yaitu dengan melakukan penelitian kepustakaan seperti bahan-bahan kepustakaan, khususnya perundang-undangan, jurnal, artikel yang berkaitan denganlalu lintas dan angkutan jalan serta ancaman atau sanksi bagi pelaku pelanggaran lalu lintas.

Pada penelitian hukum normative yuridis yaitu menelaah data sekunder,penyajian data yang dilakukan adalah berdasarkan pendekatan kualitatif yang artinya tata cara penelitian yang yang menghasilkan data deskriptif yaitu apa yang dinyatakan secara tertulis dan perilaku nyata.

\section{HASIL DAN PEMBAHASAN \\ A. Pelanggaran Lalu Lintas Dan Angkutan Jalan Berdasarkan Undang- Undang Nomor 22 Tahun 2009}

Tentang pelanggaran lalu lintas dikeluarkannya undang-undang yang mengatur lalu lintas dan angkutan jalan menjadi salah satu alternatif bagi penegak hukum setelah diberlakukanya sanksi hukuman kurungan atau denda sesuai jenis pelanggaran yang dilakukan mengingat bahwa sebelum adanya undang-undang lalu lintas dan angkutan jalan, seseorang yang melakukan pelanggaran lalu lintas hanya dipedomani dari berdasarkan Kitab Undang-Undang Hukum Acara pidana. Perkara pelanggaran lalu lintas berdasarkan pasal 211 KUHAP yaitu meliputi perkara:

a. Mempergunakan jalan dengan cara yang dapat merintangi, membahayakan ketertiban dan keamanan lalu lintas atau yang mungkin 
menimbulkan kerusakan jalan.

b. Mengemudikan kendaraan bermotor yang tidak dapat memperlihatkan Surat Izin Mengemudi (SIM), surat tanda motor kendaraan, surat tanda uji kendaraan yang sah, atau tanda bukti lainya yang diwajibkan menurut ketentuan peraturan perundang-undangan lalu lintas jalan atau ia dapat memperlihatkanya tetapi masa berlakunya sudah daluwarsa.

c. Membiarkan atau memperkenankan kendaraan bermotor dikemudikan oleh orang yang tidak memiliki surat izin mengemudi.

d. Tidak memenuhi ketentuan peraturan perundangundangan lalu lintas jalan tentang penomoran, penerangan, peralatan, perlengkapan, pemuatan kendaraan dan syarat penggandengan dengan kendaraan lain.

e. Membiarkan kendaraan bermotor yang ada dijalan, tanpa dilengkapi plat tanda nomor kendaraan yang sah, sesuai dengan nomor kendaraan yang bersangkutan.

f. Pelanggaran terhadap perintah yang diberikan oleh petugas pengatur lalu lintas jalan dan atau syarat pengatur lalu lintas jalan, ramburambu atau tanda yang ada dipermukaan jalan.

g. Pelanggaran terhadap ketentuan tentang ukuran dan muatan yang diijinkan, cara menaikkan dan menurunkan penumpang dan atau cara memuat dan membongkar barang.

h. Pelanggaran terhadap izin trayek, jenis kendaraan yang diperbolehkan beroperasi dijalan yang ditentukan.

Perkara pelanggaran lalu lintas yang diuraikan secara umum masih memilki kekurangan dalam KUHP sebab tidak dicantumkan apa sebenarnya pelanggaran itu. Karena terletak pada sanksi yang didapat maka pelanggaran dibedakan dari kejahatan.suatu tindakan dinyatakan telah melanggar apabila perbuatan itu menimbulkan adanya sifat melawan hukum dan telah ada aturan atau undang-undang yang mengaturnya, jadi jika perbuatan itu telah menimbulkan suatu sifat melawan hukum namun belum dapat dinyatakan sebagai suatu bentuk pelanggaran sebelum diatur dalam peraturan perundang-undangan.

Sebagai delik undangundang, Undang-Undang Nomor 22 Tahun 2009 mengatur pasal-pasal tentang apa yang menjadi kewajiban dan larangan bagi pengguna atau penyelenggara jalan. Berikut akan diuraikan apa saja perbuatan yang termasuk dalam kategori kewajiban yang jika tidak dipatuhi maka diartikan sebagai pelanggaran lalu lintas.
1) Pelanggaran Terhadap
Kelengkapan Menggunakan
Kendaraan Bermotor.
Kelengkapan dalam menggunakan kendaraan bermotor sangatlah penting demi kenyamanan baik bagi pengguna kendaraan atau orang lain. Undang-Undang Nomor 22 Tahun 2009 Pasal 48 menegaskan: 
(1) Setiap kendaraan bermotor yang dioperasikan di jalan harus memenuhi persyaratan teknis dan laik jalan.

(2) Persyaratan teknis yang dimaksud pada ayat (1) terdiri atas:
a. Susunan
b. Perlengkapan
c. Ukuran
d. Karoseri
e. Rancangan teknis kendaraan sesuai dengan peruntukanya
f. Pemuatan
g. Penggunaan
h. Penggandengan kendaraan bermotor;
dan/atau
i. Penempelan kendaraan bermotor

(3) Persyaratan laik jalan sebagaimana dimaksud pada ayat (1) ditentukan oleh kinerja minimal Kendaraan Bermotor yang diukur sekurang-kurangnya terdiri atas:
a. Emisi gas tabung
b. Kebisingan suara
c. Efisiensi sistem rem utama
d. Efisiensi sistem rem parkir
e. Kunci roda depan
f. Suara klakson
g. Daya pancar dan arah sinar lampu utama
h. Radius putar
i. Akurasi alat penunjuk kecepatan
j. Kesesuaian kinerja roda dan kondisi ban;/dan
k. Kesesuaian daya mesin penggerek terhadap berat kendaraan
Undang Nomor 22 Tahun 2009 Pasal 57 menegaskan :

(1) Setiap kendaraan bermotor yang dioperasikan di jalan wajib dilengkapi dengan perlengkapan kendaraan bermotor.

(2) Perlengkapan sebagaimana yang dimaksud pada ayat (1) bagi sepeda motor berupa helm standar nasional Indonesia.

(3) Perlengkapan sebagaimana yang dimaksud pada ayat (1) bagi kendaraan bermotor beroda empat atau lebih sekurang-kurangnya terdiri dari:

a. Sabuk pengaman.

b. Ban cadangan.

c. Segitiga pengaman.

d. Dongkrak.

e. Pembuka roda.

f. Helm dan rompi pemantul cahaya bagi pengemudi kendaraan bermotor beroda empat atau lebih yang tidak memilki rumah-rumah; dan

g. Peralatan pertolongan pertama pada kecelakaan lalu lintas.

4) Ketentuan lebih lanjut mengenai perlengkapan kendaraan bermotor sebagaimana dimaksud pada ayat (1), ayat (2), dan ayat (3), diatur dengan pemerintah.

Undang Nomor 22 Tahun 2009 Pasal 77 menegaskan:

(1) Setiap orang yang mengemudikan kendaraan bermotor di jalan wajib memilki Surat Izin Mengemudi sesuai dengan jenis kendaraan Bermotor yang dikemudikan. 
Pada peraturan pemerintah nomor 80 tahun 2012 tentang pemeriksaan kendaraan bermotor di jalan dan penindakan pelanggaran lalu lintas dan angkutan jalan, tujuan diadakan pemeriksaan kendaraan (razia) pada setiap jalan tertentu dilakukan karena adanya peningkatan seperti yang diuraikan pada pasal 13:

a. Angka pelanggaran dan kecelakaan lalu lintas.

b. Angka kejahatan yang menyangkut kendaraan bermotor.

c. Jumlah kendaraan bermotor yang tidak memenuhi persyaratan teknis dan persyaratan laik jalan.

d. Ketidaktaatan pemilik dan/atau pengusaha angkutan jalan untuk melakukan pengujian kendaraan bermotor pada waktunya.

e. Pelanggaran perizinan angkutan umum.

f. Pelanggaran kelebihan muatan angkutan barang.

Hal ini maka pengemudi kendaraan bermotor wajib memenuhi pasal 5 undang-undang lalu lintas jika petugas mengadakan operasi razia yaitu:

5) Pada saat diadakan pemeriksaan kendaraan bermotor di jalan setiap orang yang mengemudikan kendaraan bermotor wajib menunjukkan:

a. Surat Tanda Nomor Kendaraan Bermotor atau Surat Tanda Coba Kendaraan Bermotor.

b. Surat Izin Mengemudi.
c. Bukti lulus berkala;dan/atau
d. Tanda bukti lain yang sah.

Selanjutnya kelengkapan kendaraan bermotor roda empat di wajibkan memakai sabuk pengaman, pengendara sepeda motor wajib menggunakan helm berstandar nasional Indonesia, hal ini diatur dalam:

Undang Nomor 22 Tahun 2009 Pasal 106 menegaskan:

6) Setiap orang yang mengemudikan kendaraan bermotor beroda empat atau lebih di jalan dan penumpang yang duduk di sampingnya wajib mengenakan sebuk keselamatan

7) Setiap orang yang mengemudikan kendaraan bermotor beroda empat atau lebih yang tidak dilengkapi dengan rumah-rumah di jalan dan penumpang yang duduk disampingnya wajib mengenakan sabuk keselamatan dan mengenakan helm yang memenuhi standar nasional Indonesia.

8) Setiap orang yang mengemudikan sepeda motor dan penumpang sepeda motor wajib mengenakan helm yang memenuhi standar nasional Indonesia.

2) Pelanggaran Terhadap Tata Cara Berlalu Lintas Dan Berkendaraan.

Sebagai subyek hukum, pengemudi harus bertanggung jawab jika terjadi gangguan atau perbuatan yang dilindungi oleh undang-undang ketentuanya dan tidak memandang status seseorang.Sebagai masyarakat 
yang taat hukum harus mematuhi instruksi polisi lalu lintas yang bertugas di lapangan baik dalam menghentikan, menindak, menahan kendaraan, meminta data-data pengemudi jika terbukti melakukan pelanggaran. Pengendara diharapkan dapat melajukan kendaraan sesuai batas yang diatur dalam undangundang serta dalam keadaan konsentrasi penuh sesuai pasal 105:

(1) Berperilaku tertib; dan/

(2) Mencegah hal-hal yang dapat merintangi, membahayakan keamanan dan keselamatan lalu lintas dan angkutan jalan, atau yang dapat menimbulkan kerusakan jalan.

Pasal 104:

1) Dalam keadaan tertentu untuk ketertiban dan kelancaran lalu lintas dan angkutan jalan, Petugas Kepolisian Negara Republik Indonesia dapat melakukan tindakan:

a. Memberhentikan arus lalu lintas dan /atau pengguna jalan.

b. Memerintahkan pengguna jalan untuk jalan terus.

c. Mempercepat arus lalu lintas.

d. Memperlambat arus lalu lintas;/atau

e. Mengalihkan arus lalu lintas.

2) Tindakan sebagaimana dimaksud pada ayat (1) wajib diutamakan daripada perintah yang diberikan oleh alat pemberi isyarat lalu lintas, rambu lalu lintas, dan/atau marka jalan.

3) Pengguna jalan wajib mematuhi perintah yang dibeikan oleh petugas kepolisian negara republik
Indonesia sebagaimana yang dimaksud ayat (1).

Undang Nomor 22 Tahun 2009 Pasal 48 menegaskan:

1) Setiap orang yang mengemudikan kendaraan bermotor di jalan wajib mengemudikan kendaraanya dengan wajar dan penuh konsentrasi.

2) Setiap orang yang mengemudikan kendaraan bermotor di jalan wajib mengutamakan keselamatan pejalan kaki dan pesepeda.

3) Setiap orang yang mengemudikan kendaraan bermotor di jalan wajib mematuhi ketentuan tentang persyaratan teknis dan laik jalan.

4) Setiap orang yang mengemudikan kendaraan bermotor di jalan wajib mematuhi ketentuan:

a. Rambu perintah atau rambu larangan.

b. Marka jalan.

c. Alat pemberi isyarat lalu lintas.

d. Gerakan lalu lintas.

e. Berhenti dan parkir.

f. Peringatan dengan bunyi dan sinar.

g. Kecepatan maksimal atau minimal;dan/atau

h. Tata cara penggandengan dan penempelan dengan kendaraan lain.

Pengenaan pasal ini agak rancu jika dimaknai, sebab dilarang membawa penumpang lebih dari satu orang, pelanggaran ini paling banyak dijumpai dalam lalu lintas, anak sekolah, remaja, bahkan orangtua yang mengantar anak berboncengan 
melebihi dari yang di maksimalkan ketentuan ini, belum dengan barang bawaan kendaraan. Tidak adanya aturan batasan yang membatasi seperti apa kriteria penumpang yang bisa diangkut sepeda motor menjadikan bahwa acuan sepeda motor adalah seberapa muat orang yang bisa diangkut sepeda motor.

Alasan penggunaan lampu pada siang hari sebenarnya masih kurang diketahui masyarakat ,dalam mengurangi resiko kecelakaan lalu lintas maka kewajiban ini berguna agar pengendara mobil atau motor yang melihat spion dapat mendeteksi atau menyadari kendaraan lain dari pantulan lampu utama kendaraan, Penggunaan lampu isyarat untuk berbelok, berhenti atau mendahului juga sangat berpengaruh dalam keamanan lalu lintas, mengendarai kendaraan berdasarkan batas kecepatan maksimum sesuai keramaian dalam lalu lintas berdasarkan pasal 21 ayat (4) batas kecepatan paling rendah dalam jalan bebas hambatan adalah $60 \mathrm{~km}$ per jam.

Undang Nomor 22 Tahun 2009 Pasal 107 menegaskan:

(1) Pengemudi kendaraan bermotor wajib menyalakan lampu utama kendaraan bermotor yang digunakan di jalan pada malam hari dan pada kondisi tertentu.

(2) Pengemudi sepeda motor selain mematuhi ketentuan sebagaimana dimaksud ayat (1) wajib menyalakan lampu utama pada siang hari.

\section{B. Faktor-Faktor Penyebab Pelanggaran Lalu Lintas}

Berikut beberapa faktor penyebab pelanggaran lalu lintas yang marak terjadi di Indonesia bahkan kemungkinan besar juga dijumpai di kota medan yaitu:

1. Minimnya pengetahuan mengenai peraturan, marka, dan rambu lalu lintas. Tidak semua pengemudi kendaraan paham dan mengetahui peraturanperaturan lalu lintas, arti dari marka jalan, serta arti dari rambu-rambu lalu lintas. Hal ini disebabkan bahwa kurangnya kesadaran untuk mencari tahu arti dari simbol-simbol lalu lintas tersebut, ditambah kemungkinan besar pengurusan Surat Izin Mengemudi lebih didapat secara instan daripada mengikuti seluruh prosedur yang dianggap berbelit-belit atau memakan waktu agak lama.

2. Kesadaran masyarakat dalam lalu lintas. Masyarakat di Indonesia yang berpatokan pada undang-undang tetapi masih memilki tingkat kesadaran yang rendah dalam menaatinya.

3. Kendaraan yang tidak layak atau melebihi ketentuan standar.

4. Anak dibawah umur yang menyikapi orang dewasa dalam melanggar lalu lintas. Hal ini terlihat biasa tetapi dengan bersamaan anak dengan orangorang sekitar yang berkendaraan, anak tersebut bukan tidak bisa di simpulkan dapat mencontoh orang dewasa yang melanggar aturan rambu lalu lintas sehingga anak yang berkendara dapat menjadi potensi banyak pelanggaran lalu lintas terutama tidak adanya Surat Izin Mengemudi atau tidak memakai helm.

5. Kepatuhan masyarakat hanya berpotensi kepada petugas yang berada di lapangan. Banyak ditemui pengemudi lalu lintas 
tidak mengindahkan peraturan yang ada dalam undang-undang karena penerapanya yang sudah tertulis hanya dianggap formalitas saja tanpa praktek sesuai kenyataan. Banyak pengemudi hanya mengandalkan rasa takut berkendara jika ada petugas atau kepolisian yang bertugas. Hanya polisi, adanya petugas yang dari dinas perhubungan masyarakat tidak takut karena mereka dianggap tak layak untuk menilang.

6. Anggapan bahwa memang aturan itu dibuat untuk dilanggar. Mungkin bukan orang hukum saja yang tahu dan mengerti apa yang diartikan dengan " Aturan dibuat Untuk Dilanggar". Sungguh ironis masyarakat kita masih sedikit paham untuk apa hukum atau aturan dibuat.

7. Damai adalah kebiasaan dalam penerapan tilang. Inilah yang paling banyak dijumpai. Ketika begitu banyaknya pengemudi yang ditahan dan ditilang, masyarakat yang melanggar akan mengajukan damia kepada polisi di jalan, bahkan jika tidak damai di jalan bisa juga damai sebelum pengadilan demi mendapatkan surat-surat yang ditahan oleh pihak kepolisian.

\section{KESIMPULAN}

Berdasarkan hasil penelitian yang telah dilakukan dan dijabarkan oleh peneliti, maka peneliti menyimpulkan hal-hal sebagai berikut :

1. Pelanggaran Lalu Lintas dan Angkutan Jalan diatur dalam Undang-Undang No.22 Tahun
2009 tentang Lalu Lintas dan Angkutan Jalan memuat pasalpasal yang menjadi kewajiban dan larangan bagi pengguna jalan ataupun penyelanggara lalu lintas. Kewajiban tersebut adalah aturan yang harus dipenuhi oleh pengguna jalan agar tidak terjadi pelanggaran. yang menjadi jenis perbuatan pelanggaran lalu lintas yang ada dalam undang-undang ini yaitu pelanggaran terhadap kelengkapan menggunakan kendaraan bermotor, pelanggaran terhadap tata cara berlalu lintas dan berkendaraan, pelanggaran terhadap fungsi jalan dan rambu lalu lintas dan pelanggaran terhadap kendaraan bermotor umum.

2. Pelanggaran lalu lintas diatas tidak terlepas dari faktor-faktor yang menyebabkan timbulnya pelanggaran lalu lintas yang terdiri dari pengemudi atau pengendara, pejalan kaki, kendaraan dan kondisi jalan.

\section{DAFTAR PUSTAKA}

\section{A. Buku-Buku}

$\begin{array}{cr}\text { Asyhadie Zaeni dan } & \text { Rahman } \\ \text { Arief.2012.Pengantar } & \text { Ilmu } \\ \text { Hukum.Jakarta:PT } & \text { Raja } \\ \text { Grafindo Persada. } & \end{array}$

Bambang Poernomo, Asas-Asas Hukum Pidana, Ghalia Indonesia, Jakarta: 1987.

Chazawi, Adami, Pembelajaran Hukum Pidana Satu, Rajawali Pers, Jakarta:201

Hamzah,Andi., Bunga Rampai
Hukum Pidana dan Acara
Pidana, Ghalia Indonesia,
Jakarta: 1986.


Johan Nasution, Bahder., Metode Penelitian Ilmu Hukum, CV. Mandar Maju, Bandung: 2008.

Soeroso R.1992. Pengantar Ilmu Hukum.Jakarta:Sinar Grafika.

Soekanto, Soerjono., Metode Penelitian

Hukum.Jakarta:Penerbit Universitas Indonesia:1984.

B. Perundang-Undangan

Undang-Undang Nomor 22 Tahun 2009 Tentang Lalu Lintas Dan Angkutan Jalan

Undang-Undang Nomor 2 Tahun 2002 Tentang Kepolisian Negara Republik Indonesia

Peraturan Pemerintah Republik Indonesia Nomor 80 Tahun 2012 Tentang Tata Cara

Pemeriksaan Kendaraan Bermotor Di Jalan Dan Penindakan Pelanggaran Lalu Lintas Dan Angkutan Jalan di Indonesia

\section{Jurnal, Makalah Dan Lain- Lain}

Dewi Handayani, Rahma Ori Ophelia dan Widi Hartono, "Pengaruh Pelanggaran Lalu Lintas Terhadap Potensi Kecelakaan Pada Remaja Pengendara Sepeda Motor".e-jurnal MATRIKS TEKNIK SIPIL/September 2017.

Ariefulloh, et al. (2019)."Dilema Penerapan Sanksi Pelanggaran Lalu Lintas Terhadap Anak".Jambura Law Review, JALREV 1 (2): $192-211$ (2019).

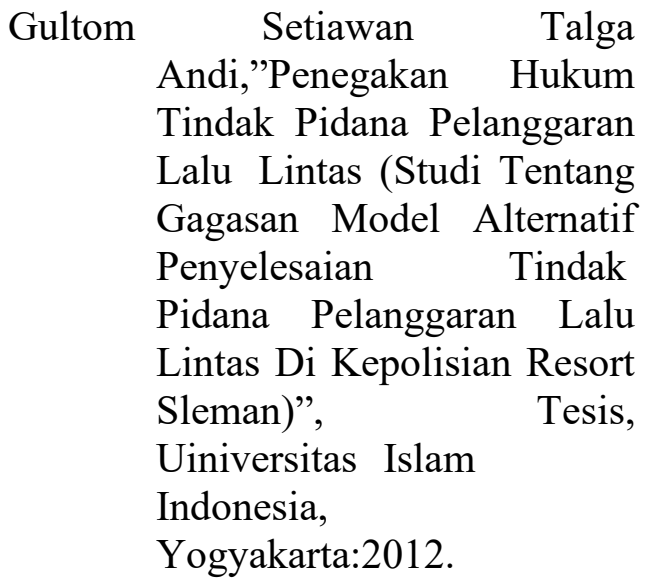

\section{Internet.}

https://medan.tribunnews.com/2019/

11/06/ops-zebra-2019-poldasumut-catat- jumlahpelanggaran-53659-atau-naik-5persen-dari-tahun-lalu?page $=1$.

diakses pada 22 april 2020. Pukul 10.03 wib

https://www.merdeka.com/peristiwa/ kecelakaan-beruntun-di-medanjazz-sampai- tertindihpajero.html. Diakses pada 27 april 2020. Pukul 10.01 wib.

https://www.mistar.id/hukumperistiwa/ditabrak-mobil-boxwanita-cantik-tewas/.Diakses pada 22 juli 2020.Pukul 09:35 wib.

https://www.liputan6.com/otomotif/r ead/3242446/ingat-alasansepeda-motor- wajibmenyalakan-lampu-di-siang-hari. Diakses pada 27 juni 2020, jam $11.05 \mathrm{wib}$ 